\title{
OLAHRAGA DAN REGULASI EMOSI: SEBUAH STUDI KORELASI PADA TARUNA PERGURUAN TINGGI KEDINASAN (PTK)
}

\author{
Juandita Widowianti Permono, \\ Chandradewi Kusristanti ${ }^{I}$ \\ Fakultas Psikologi \\ Universitas YARSI \\ Jl. Letjend Soeprapto \\ Cempaka Putih, Jakarta, 10410, Indonesia \\ 'e-mail: chandradewi.k@gmail.com
}

\begin{abstract}
Cadets as students of the School of Services face many kinds of demands. Those demands may trigger both academic and non-academic stress. An effect of stress is emotional response, which needs to be handled. Therefore, cadets need to regulate their emotion. Exercise is a mandatory activity in School of Service. The purpose of this study is to know if there is any relation between exercise and emotion regulation of cadets in School of Services. Using stratified random sampling, the number of participants in the present study is 270 cadets. Questionnaires used in this study are International Physical Activity Questionnaire (IPAQ) and Emotion Regulation Questionnaire (ERQ) that have been adapted. Results showed that there is no significant relationship between exercise and emotion regulation reappraisal $(r=.109, p=.074)$ as well as exercise and emotion regulation suppression $(r=.031, p=.612)$ among participants.
\end{abstract}

Keywords: Exercise; emotion regulation; physical activity; stress.

\begin{abstract}
Abstrak - Taruna sebagai siswa pada Perguruan Tinggi Kedinasan (PTK) dihadapkan pada berbagai macam tuntutan, baik akademik maupun non-akademik, yang dapat memicu stres. Salah satu respons yang dihasilkan oleh stres yaitu respons emosional. Respons emosi dari stres tersebut perlu ditangani agar tidak memberikan efek yang lebih besar kepada para taruna. Oleh karena itu, para taruna perlu meregulasi emosinya. Salah satu kegiatan yang dapat dilakukan taruna terkait upaya regulasi emosi dan juga yang menjadi karakteristik dari PTK yaitu aktivitas fisik berupa olahraga wajib. Penelitian ini bertujuan untuk mengetahui apakah terdapat hubungan yang signifikan antara olahraga dengan regulasi emosi pada taruna PTK. Sampel penelitian berjumlah 270 orang taruna yang dipilih dengan menggunakan teknik sampling (stratified random sampling). Penelitian ini menggunakan alat ukur adaptasi dari International Physical Activity Questionnaire (IPAQ) dan Emotion Regulation Questionnaire. Hasil uji korelasi menunjukkan bahwa tidak terdapat hubungan
\end{abstract}


yang signifikan antara olahraga dengan regulasi emosi reappraisal $(r=.109, p=.074)$ maupun supresi $(r=.031, p=.612)$.

Kata Kunci: Olahraga; regulasi emosi; aktivitas fisik; stres.

\section{PENDAHULUAN}

Taruna memiliki berbagai tuntutan dalam lingkungan pendidikannya. Tidak hanya dituntut untuk tetap prima dalam kegiatan fisik, para taruna juga harus dapat menampilkan performa akademik yang baik di tengah kepadatan kegiatannya, serta kondisi lingkungan dengan kedisiplinan yang sangat ketat. Kedua tuntutan yang ada tersebut dapat memicu stres pada para taruna. Salah satu respons yang dihasilkan oleh stres yaitu respons emosional (Putri, 2015). Apabila tidak siap menghadapi beban tuntutan yang sedemikian banyaknya, maka hal tersebut akan berpengaruh pada penurunan performa taruna. Lebih jauh lagi, respons emosi dari stres tersebut menjadi perlu untuk ditangani agar tidak memberikan efek lebih besar bagi para taruna, seperti keadaan depresi atau gangguan emosional lain (Putri, 2015). Untuk itu, para taruna perlu meregulasi emosinya agar dapat beradaptasi dengan baik terhadap lingkungannya yang penuh dengan berbagai macam tuntutan, baik akademik maupun non-akademik.

Gross (dalam Mayangsari, 2014) mendefinisikan regulasi emosi sebagai kemampuan yang dimiliki seseorang untuk menilai, mengatasi, mengelola, dan mengungkapkan emosi yang tepat untuk mencapai keseimbangan emosional. Menurut Gross (2002), strategi regulasi emosi dibagi menjadi dua, yaitu reappraisal dan supresi. Reappraisal terjadi lebih awal pada proses emotion-generative, melibatkan cara berpikir seseorang tentang situasi untuk mengurangi dampak emosionalnya. Supresi terjadi setelah reappraisal pada proses emotion-generative. Supresi menghambat tanda-tanda yang tampak dari perasaan batin, menurunkan pengalaman emosi, serta meningkatkan respons fisiologis pada penekan dan mitra sosialnya. Beberapa studi menemukan bahwa reappraisal sering kali lebih efektif dari supresi (Gross, 2002).

Salah satu upaya regulasi emosi adalah response modulation, yakni dengan memengaruhi respons fisiologis, pengalaman, atau perilaku dengan seketika. Contoh dari strategi ini adalah melalui olahraga, relaksasi, dan musik, yang dapat digunakan untuk menurunkan aspek emosi negatif, seperti emosi marah dan sedih (Putri, 2015). Kegiatan yang dapat dilakukan para taruna terkait upaya regulasi emosi, dan juga menjadi karakteristik dari Perguruan Tinggi Kedinasan (PTK) adalah adanya aktivitas fisik berupa olahraga wajib yang dilakukan setiap pagi dan sore hari, serta aktivitas olahraga lainnya. 
Hubungan antara olahraga dengan emosi dapat dilihat dari tinjauan neuropsikologi. Menurut Rafey (dalam Ambardini, 2009) terdapat beberapa neurotransmiter yang berhubungan dengan latihan fisik, yaitu neurotransmiter yang tergolong dalam monoamin (norepinefrin, serotonin, dan dopamin). Norepinefrin berfungsi untuk memperbaiki suasana hati (mood), motivasi intrinsik, rasa percaya diri, dan memperbaiki persepsi diri. Sementara itu, serotonin berfungsi mengatur suasana hati, mengendalikan impuls, menimbulkan rasa percaya diri, melawan efek racun dari tingginya kadar hormon stres, dan memperbaiki proses belajar pada tingkat seluler. Latihan yang teratur juga dapat meningkatkan jumlah enzim yang menghasilkan dopamin, dan mengubah kerja dopamin pada membran postsynaptic. Latihan fisik cenderung meningkatkan kadar glukosa, serotonin, epinefrin, dopamin (zat-zat kimia saraf) yang berpengaruh pada pengaturan perilaku.

Menurut Rafey (dalam Ambardini, 2009), latihan fisik dapat meningkatkan perhatian dan motivasi, melalui peningkatan kadar dopamin dan norepinefrin, sehingga membuat suasana hati lebih positif, menurunkan kecemasan, dan meningkatkan rasa percaya diri. Latihan fisik juga dapat meningkatkan serotonin (Ambardini, 2009). Serotonin merupakan neurotransmiter monoamin ketiga yang disebut juga 5-HT, alias 5-hidroksitriptamin. Efek-efeknya terhadap perilaku bersifat kompleks. Serotonin memainkan peran dalam regulasi suasana hati, kontrol tindakan makan, tidur, dan terjaga, serta dalam regulasi nyeri (Carlson, 2012).

Berdasarkan hasil wawancara, beberapa taruna pada salah PTK menyatakan bahwa aktivitas fisik berupa olahraga yang mereka lakukan hampir setiap hari, membuat mereka merasa lebih bersemangat dalam melakukan aktivitas-aktivitas lainnya, serta membuat suasana hati mereka lebih baik. Namun, ketika tidak mengikuti aktivitas tersebut, mereka merasa lebih malas untuk melakukan aktivitas-aktivitas lainnya. Berdasarkan data awal yang diperoleh tersebut, dapat dikatakan bahwa aktivitas fisik berupa olahraga yang dilakukan para taruna tersebut dapat memunculkan emosi positif. Dengan munculnya emosi positif dari aktivitas olahraga tersebut, maka olahraga dapat menjadi salah satu sarana bagi para taruna dalam meregulasi emosinya.

Dengan melakukan aktivitas fisik berupa olahraga rutin setiap harinya, diharapkan para taruna dapat melakukan regulasi emosi yang baik dalam lingkungan pendidikannya. Taruna yang memiliki kemampuan regulasi emosi yang baik juga akan mampu mengontrol emosinya dengan baik pula. Salah satunya ialah mengontrol keluarnya emosi negatif, seperti marah dan kesal, melalui perilaku agresif seperti memukul. Oleh karena itu, peneliti ingin membuktikan apakah olahraga memiliki hubungan dengan regulasi emosi pada taruna PTK. 
Tujuan dari penelitian ini adalah untuk mengetahui hubungan antara olahraga dengan regulasi emosi pada taruna PTK. Secara teoretis, hasil dari penelitian ini diharapkan dapat menjadi referensi atau masukan bagi perkembangan ilmu psikologi dan menambah kajian ilmu psikologi, khususnya dalam bidang klinis pada instansi pendidikan tentang hubungan antara aktivitas fisik dengan kemampuan regulasi emosi pada mahasiswa. Sementara itu, secara praktis hasil penelitian ini diharapkan dapat menjadi masukan bagi pihak perguruan tinggi kedinasan terkait dengan penerapan aktivitas fisik berupa olahraga bagi mahasiswanya.

\section{METODE}

\section{Partisipan}

Populasi pada penelitian ini adalah taruna PTK X, Y, dan Z. Sampel dalam penelitian ini adalah 270 orang taruna dari PTK X, Y, dan Z yang terdiri dari 90 orang taruna dari masing-masing PTK. Teknik sampling yang digunakan adalah proportionate stratified random sampling. Proportionate stratified random sampling digunakan apabila populasi memiliki anggota atau unsur yang tidak homogen dan berstrata secara proporsional (Sugiyono, 2012).

\section{Desain}

Penelitian ini menggunakan pendekatan kuantitatif. Penelitian kuantitatif merupakan penelitian yang dimaksudkan untuk memperoleh data dalam bentuk kuantifikasi, yaitu bentuk angka (Sugiyono, 2012). Rancangan penelitian yang digunakan adalah korelasional, yaitu suatu penelitian yang menghubungkan satu atau lebih variabel bebas dengan satu variabel terikat tanpa ada upaya untuk memengaruhi variabel tersebut (Maksum, dalam Risal, 2013). Variabel dalam penelitian ini yaitu olahraga dan regulasi emosi.

\section{Prosedur}

Tahap persiapan dalam penelitian ini diawali dengan mencari masalah yang menarik untuk diteliti. Hal ini dilakukan dengan mencari berbagai informasi melalui artikel serta wawancara. Masalah penelitian ini kemudian dikembangkan dengan menyusun latar belakang serta melakukan tinjauan kepustakaan sesuai dengan masalah yang ingin diteliti. Peneliti kemudian merancang metode penelitian serta memilih alat ukur yang akan digunakan. Penelitian ini menggunakan kuesioner sebagai metode 
pengambilan data. Kuesioner merupakan teknik pengumpulan data yang efisien, di mana responden diminta untuk mengisi pertanyaan atau pernyataan yang diberikan kepada responden secara langsung atau dikirim melalui pos ataupun internet (Sugiyono, 2011).

Pada tahap pelaksanaan, peneliti melakukan uji coba pada alat ukur yang telah dipilih. Pengukuran variabel dalam penelitian ini dilakukan dengan menggunakan alat ukur yang diadaptasi dari International Physical Activity Questionnaire (IPAQ). Kuesioner aktivitas yang digunakan disesuaikan dengan kegiatan olahraga wajib yang dilakukan oleh subjek dalam penelitian, yaitu lari, push up, sit up, dan senam. Alat ukur tersebut mengukur durasi olahraga wajib yang dilakukan oleh subjek. Alat ukur lain yang digunakan yaitu Emotion Regulation Questionnaire (ERQ) yang dirancang oleh Gross dan John (2003). ERQ merupakan kuesioner yang berisi 10 butir pernyataan yang menggunakan dua bentuk strategi regulasi emosi sebagai dimensinya, yaitu cognitive reappraisal dan expressive suppression. Berdasarkan hasil uji coba alat ukur dengan jumlah sampel 55 orang, diperoleh angka reliabilitas internal untuk alat ukur ERQ sebesar .734 untuk dimensi reappraisal dan .639 untuk dimensi supresi. Setelah memastikan bahwa alat ukur yang dipakai valid dan reliabel, peneliti kemudian menyebarkan alat ukur kepada partisipan yang memenuhi kriteria.

Pada tahap pelaporan, peneliti melakukan pengolahan serta analisis data berdasarkan hasil yang telah diperoleh. Selanjutnya, peneliti menyusun pembahasan hasil pengolahan dan analisis data hingga dapat memperoleh kesimpulan dan saran. Tahap terakhir adalah melaporkan hasil penelitian ini.

\section{Teknik Analisis}

Pengolahan data dilakukan dengan menggunakan software SPSS 17.0. Peneliti melakukan uji normalitas terlebih dahulu dengan menggunakan uji Kolmogorov-Smirnov. Hasil penyebaran data yang tidak normal membuat peneliti melakukan uji korelasi dengan menggunakan teknik Spearman.

\section{ANALISIS DAN HASIL}

\section{Uji Normalitas}

Dimensi reappraisal ( $p=.096)$ dan supresi $(p=.069)$ pada regulasi emosi berdistribusi normal. Di sisi lain, untuk variabel olahraga ditemukan penyebaran yang tidak terdistribusi normal $(p=.003)$. 
Tabel 1.

Uji Normalitas

\begin{tabular}{lcc}
\hline \multicolumn{1}{c}{ Variabel } & K.SZ & Sig. (2 tailed) \\
\hline Regulasi Emosi & & \\
1. Reappraisal & 1.232 & .096 \\
2. Supresi & 1.297 & .069 \\
\hline Olahraga & 1.821 & .003 \\
\hline
\end{tabular}

\section{Uji Korelasi}

Berdasarkan uji korelasi Spearman, diketahui bahwa reappraisal tidak berhubungan secara signifikan dengan olahraga, begitu pula dengan supresi yang tidak berhubungan dengan olahraga.

Tabel 2.

Korelasi Olahraga dan Dimensi Regulasi Emosi

\begin{tabular}{ccc}
\hline Variabel & Regulasi Emosi Reappraisal & Regulasi Emosi Supresi \\
\hline Olahraga & .109 & .031 \\
\hline
\end{tabular}

Uji korelasi pada tabel di atas menunjukkan bahwa tidak terdapat korelasi antara olahraga dengan regulasi emosi reappraisal $(r=.109 ; p=.074)$. Di sisi lain, olahraga juga tidak berkorelasi dengan regulasi emosi supresi $(r=.031 ; p=.612)$.

\section{DISKUSI}

Hasil analisis menunjukkan bahwa tidak terdapat hubungan yang signifikan antara durasi berolahraga wajib dengan regulasi emosi reappraisal. Data juga menunjukkan bahwa tidak terdapat hubungan yang signifikan antara durasi berolahraga wajib dengan regulasi emosi supresi. Hal ini menunjukkan bahwa hipotesis penelitian ditolak. Temuan tersebut tidak sejalan dengan sejumlah literatur yang menyatakan bahwa olahraga merupakan salah satu upaya dalam meregulasi emosi. Menurut Gross (dalam Putri, 2015), terdapat berbagai upaya yang berbeda untuk meregulasi emosi di mana terdapat perbedaan pula dalam waktu penggunaannya. Salah satu upaya tersebut adalah response modulation, yaitu dengan memengaruhi respons fisiologis atau pengalaman. Contoh dari upaya ini adalah melalui olahraga, relaksasi, dan musik. Hasil penelitian ini pun tidak sejalan dengan penelitian sebelumnya yang dilakukan oleh Goodwin, Haycraft, dan Meyer (2012) yang menemukan bahwa 
terdapat hubungan antara olahraga dengan salah satu dimensi regulasi emosi, yaitu internal functional. Internal functional merujuk pada perilaku yang lebih adaptif seperti reappraisal.

Berdasarkan literatur, diketahui bahwa terdapat beberapa neurotransmiter yang berhubungan dengan olahraga, yaitu neurotransmiter yang tergolong dalam neurotransmiter monoamin (norepinefrin, serotonin, dan dopamin). Latihan fisik cenderung meningkatkan kadar glukosa, serotonin, epinefrin, dan dopamin (zat-zat kimia saraf) yang berpengaruh pada pengaturan perilaku. Akan tetapi, dalam penelitian ini tidak dilakukan pengukuran secara komprehensif terhadap berbagai macam kegiatan fisik yang dilakukan oleh subjek, seperti olahraga futsal, bulu tangkis, renang, dan lainnya. Peneliti hanya mengukur kegiatan wajib yang dilakukan oleh subjek, yaitu lari, senam, sit up, dan push up. Hal tersebut dapat memengaruhi hasil dari penelitian. Peneliti menduga bahwa tidak terdapatnya hubungan antara olahraga dengan regulasi emosi disebabkan juga oleh kegiatan fisik lain yang dilakukan oleh subjek namun tidak terukur dalam penelitian ini.

Pada wawancara dengan sejumlah taruna dari PTK X dan Z, beberapa subjek mengatakan bahwa mereka tidak merasakan adanya perbedaan yang signifikan terkait dengan kondisi emosi saat mereka melakukan olahraga ataupun tidak, dan pada awalnya, mereka pun merasa menjadi lebih lelah dengan adanya kegiatan tersebut. Hasil wawancara tersebut menunjukkan bahwa sebagian taruna merasa olahraga yang mereka lakukan menjadi beban yang membuat mereka merasa lelah. Penelitian yang dilakukan Budiman, Minarsih, dan Hasiholan (2016) menemukan bahwa beban kerja berpengaruh secara signifikan terhadap stres. Oleh karena itu, peneliti menduga bahwa beberapa subjek merasa stres karena terbebani dengan kegiatan olahraga yang mereka lakukan, sehingga hal tersebut pun memengaruhi hasil penelitian.

Towbes dan Cohen (dalam Wike, 2015) mengukur enam stresor utama pada mahasiswa. Keenam stresor utama tersebut adalah: prestasi akademik, hubungan dengan teman dekat, hubungan dengan anggota keluarga, hubungan romantis, perbedaan gaya hidup, serta aktivitas fisik dan penampilan. Berdasarkan hal tersebut, diketahui bahwa aktivitas fisik menjadi salah satu stresor dari stres pada mahasiswa. Oleh karenanya, olahraga, sebagai bagian dari aktivitas fisik, juga berpotensi memengaruhi kemampuan subjek dalam meregulasi emosinya. Penelitian yang dilakukan oleh Hervina dan Anggraeni (2014) menyatakan bahwa terdapat hubungan antara regulasi emosi dan stres, di mana semakin tinggi stres maka semakin tinggi pula kesulitan untuk meregulasi emosi, begitu pula sebaliknya.

Hasil penelitian ini sejalan dengan penelitian yang dilakuan Sundari (2012) yang menyatakan bahwa tidak terdapat hubungan antara stres dengan olahraga pada mahasiswa. Penelitian lainnya yang 
dilakukan Nguyen-Michael, Unger, Hamilton, dan Spruijt-Metz (dalam Wike, 2015) juga menemukan bahwa tidak terdapat hubungan yang signifikan antara aktivitas fisik dan stres pada mahasiswa. Berdasarkan hasil penelitian tersebut, peneliti menduga bahwa aktivitas fisik berupa olahraga tidak berhubungan dengan emosi sebagai salah satu respons dari stres pada mahasiswa. Menurut Sarfino (dalam Sundari, 2012), individu dapat mengatur emosinya dengan beberapa cara, antara lain dengan melakukan aktivitas yang disukai seperti olahraga atau menonton film, berbelanja, dan bermain games. Hal tersebut menunjukkan bahwa olahraga bukan merupakan satu-satunya upaya subjek untuk meregulasi emosi. Terdapat upaya lain yang dapat dilakukan oleh subjek dalam meregulasi emosinya selain dengan melakukan olahraga.

Gross (dalam Azmi, 2016) menyebutkan tiga faktor yang dapat memengaruhi regulasi emosi, yaitu tujuan dilakukannya regulasi emosi, frekuensi seseorang melakukan regulasi emosi, dan kepribadian. Faktor pertama yang dapat memengaruhi regulasi emosi yaitu tujuan dilakukannya regulasi emosi. Gross (dalam Azmi, 2016) menyatakan tujuan dilakukannya regulasi emosi merupakan hal-hal yang diyakini individu dapat memengaruhi pengalaman, ekspresi emosi, dan respons fisiologis yang sesuai dengan situasi yang dialami. Dalam hal ini, subjek penelitian tidak menyadari bahwa kegiatan olahraga yang mereka lakukan setiap harinya dapat menjadi salah satu upaya dalam meregulasi emosi. Hal ini sesuai dengan hasil wawancara peneliti terhadap beberapa subjek pada PTK X dan Z yang menyatakan bahwa mereka melakukan kegiatan olahraga karena kegiatan tersebut merupakan kegiatan wajib yang harus mereka lakukan setiap harinya, apabila tidak dilakukan secara sengaja maka mereka akan mendapat hukuman. Selain itu, beberapa subjek pun mengatakan bahwa mereka tidak merasakan adanya perbedaan yang signifikan terkait dengan kondisi emosi saat mereka melakukan olahraga ataupun tidak. Oleh karena itu, peneliti berasumsi bahwa beberapa subjek hanya melakukan kegiatan olahraga untuk mematuhi peraturan yang sudah ada dan tidak melakukan kegiatan tersebut sebagai upaya untuk meregulasi emosinya, sehingga hal tersebut memengaruhi hasil dari penelitian ini.

Faktor kedua yang dapat memengaruhi regulasi emosi adalah frekuensi, yaitu seberapa sering seseorang melakukan regulasi emosi dengan berbagai cara yang berbeda (Gross, dalam Azmi, 2016). Selain berolahraga, subjek pun dapat melakukan kegiatan lainnya sebagai upaya dalam meregulasi emosinya. Namun, karena berada di lingkungan PTK yang identik dengan kegiatan aktivitas fisik yang padat, membuat subjek akan lebih banyak pula melakukan kegiatan olahraga. Berdasarkan data kegiatan aktivitas fisik yang diukur, sebagian besar subjek melakukan olahraga dengan durasi yang 
cukup tinggi. Saat mewawancarai sejumlah subjek pada PTK X dan Z, beberapa subjek mengatakan bahwa mereka merasa memiliki emosi yang lebih baik apabila melakukan olahraga. Akan tetapi, sebagian lainnya mengatakan bahwa mereka tidak merasakan adanya perbedaan yang signifikan terkait dengan kondisi emosi mereka saat melakukan olahraga ataupun tidak. Pada awalnya mereka merasa menjadi lebih lelah dengan adanya kegiatan olahraga, namun akhirnya mereka mulai terbiasa dengan banyaknya aktivitas fisik tersebut. Dalam penelitian ini, upaya meregulasi emosi lain yang mungkin dilakukan subjek tidak diketahui secara jelas, sehingga tidak dapat diketahui bagaimana pengaruhnya terhadap regulasi emosi dari subjek.

Faktor ketiga yang memengaruhi regulasi emosi adalah kepribadian. Kemampuan seseorang dalam melakukan regulasi emosi dapat dipengaruhi oleh keunikan dari trait yang dimilikinya (Azmi, 2016). Penelitian yang dilakukan oleh Terracciano, Merritt, Zonderman, dan Evans (dalam Trógolo \& Medrano, 2012) menemukan bahwa kepribadian openness berkorelasi dengan kemampuan untuk mengenali emosi. Sementara itu, penelitian yang dilakukan oleh McCrae dan Costa (dalam Trógolo \& Medrano, 2012) menemukan bahwa kepribadian agreeableness berhubungan dengan bagaimana individu mengekspresikan emosi negatifnya.

Terdapat pula beberapa faktor lain yang dapat memengaruhi regulasi emosi seseorang, salah satunya jenis kelamin. Menurut Fischer (dalam Azmi, 2016), perbedaan jenis kelamin dalam mengekspresikan emosi dihubungkan dengan perbedaan tujuan laki-laki dan perempuan dalam mengontrol emosinya. Perempuan lebih mengekspresikan emosi untuk menjaga hubungan interpersonal serta membuat mereka tampak lemah dan tidak berdaya. Sebaliknya, laki-laki lebih mengekspresikan marah dan bangga untuk mempertahankan dan menunjukkan dominasi. Salovey dan Sluyter (dalam Estefan, 2014) menyimpulkan bahwa anak perempuan lebih banyak mencari dukungan dan perlindungan dari orang lain untuk meregulasi emosi negatif mereka sedangkan anak laki-laki menggunakan latihan fisik untuk meregulasi emosi negatif mereka. Hal tersebut sejalan dengan hasil penelitian ini di mana pada uji beda subjek laki-laki $(M=153.12, S D=0.454)$ memiliki aktivitas olahraga yang lebih tinggi daripada subjek perempuan $(M=92.12, S D=0.454)$. Hal tersebut menunjukkan bahwa subjek laki-laki memiliki aktivitas olahraga yang lebih tinggi daripada subjek perempuan. Hal itu dapat dilatarbelakangi oleh perbedaan anatomis serta fisiologis pada laki-laki dan perempuan. Velle (dalam Sutresna, 1999) menjelaskan bahwa aktivitas jasmani laki-laki lebih tinggi karena pengaruh hormon dalam otak selama perkembangan janin. 


\section{SIMPULAN DAN SARAN}

\section{Simpulan}

Hasil yang diperoleh dari penelitian ini menunjukkan bahwa tidak terdapat hubungan yang signifikan antara aktivitas fisik dengan regulasi emosi reappraisal maupun supresi pada taruna PTK.

\section{Saran Teoretis}

Untuk penelitian selanjutnya, apabila ingin melakukan penelitian dengan variabel olahraga, perlu diperhatikan lagi macam-macam kegiatan olahraga yang biasa dilakukan oleh subjek. Untuk mendapatkan pemahaman yang lebih komprehensif, diharapkan penelitian selanjutnya juga menelaah faktor lain yang dapat memengaruhi hasil penelitian, seperti contohnya kepribadian.

\section{Saran Praktis}

Bagi institusi, hasil penelitian ini dapat dijadikan masukan untuk menyediakan sarana bagi para taruna untuk dapat meregulasi emosinya melalui hal-hal yang diminati oleh taruna, seperti menyediakan kegiatan seni dan rohani. Sementara itu, bagi taruna kedinasan, sebagai subjek dalam penelitian ini, dapat mengetahui bahwa aktivitas fisik dapat menjadi salah satu upaya untuk meregulasi emosi, namun kegiatan tersebut bukanlah satu-satunya yang dapat dilakukan sebagai upaya dalam meregulasi emosi. Terdapat kegiatan-kegiatan lain yang diminati oleh taruna yang juga dapat menjadi upaya dalam meregulasi emosi, seperti mengikuti kegiatan seni, rohani, bermain games, dan berkumpul dengan teman-teman di asrama.

\section{REFERENSI}

Ambardini, R. L. (2009). Pendidikan jasmani dan prestasi akademik: tinjauan neurosains. Jurnal Pendidikan Jasmani Indonesia, 6(1), 46-52.

Azmi, S. F. (2016). Perbedaan regulasi emosi pada mahasiswa rantau remaja akhir yang melakukan cybercatharsis di blog dan yang tidak serta tinjauannya menurut islam (Skripsi tidak dipublikasikan). Universitas YARSI, Indonesia. 
Budiman A., Minarsih, M. M., \& Hasiholan, L. B. (2016). Effect of leadership, workload, and conflict of work stress impact on employees that intensity of turnover employees cv jati utama semarang. Journal of Management, 2(2), 1-15.

Carlson, N. R. (2012). Fisiologi perilaku (11th ed.). Jakarta, Indonesia: Erlangga.

Estefan, G. (2014). Gambaran proses regulasi emosi pada pelaku self injury (Skripsi tidak dipublikasikan). Universitas Esa Unggul, Indonesia.

Gross, J. J. (2002). Emotion regulation: Affective, cognitive, and social consequences. Psychophysiology, 39, 281-291.

Gross, J. J., \& John, O. P. (2003). Individual differences in two emotion regulation processes: Implication for affect, relationships, and well-being. Journal of Personality and Social Psychology, 85, 348-362.

Hervina, R. D., \& Anggraeni, P. (2014). Hubungan antara regulasi emosi dengan tingkat stres pada ibu tunggal (single mother) (Skripsi tidak dipublikasikan). Fakultas Psikologi Universitas Gunadarma, Indonesia.

Mayangsari, E. D. (2014). Hubungan kecemasan dan regulasi emosi pada penyidik serta tinjauannya dalam islam (Skripsi tidak dipublikasikan). Universitas YARSI, Indonesia.

Putri, R. I. A. (2015). Regulasi emosi pada mahasiswa fakultas psikologi universitas padjajaran yang bermain angklung (Thesis Diploma tidak dipublikasikan). Universitas Padjajaran, Indonesia.

Risal, A. F. (2013). Hubungan aktivitas fisik terhadap stabilitas emosi anak tuna rungu (studi pada siswa tingkat SMP di SLB gedangan Sidoarjo). Jurnal Pendidikan Olahraga dan Kesehatan, $1(3), 487-491$.

Sugiyono. (2011). Metode penelitian pendidikan. Bandung, Indonesia: Alfabeta.

Sugiyono. (2012). Metode penelitian kualitatif, kuantitatif, dan R \& D. Bandung, Indonesia: Alfabeta.

Sundari, J. (2012). Hubungan antara tingkat stres dengan intensitas olahraga pada mahasiswa reguler 2008 fakultas matematika dan ilmu pengetahuan alam universitas indonesia (Skripsi tidak dipublikasikan). Universitas Indonesia, Indonesia.

Sutresna, N. (1999). Wanita dan olahraga (fenomena sosial). Dalam H. Harsuki \& S. Elias (Eds.), Perkembangan olahraga terkini: Kajian para pakar (h. 253-268). Jakarta, Indonesia: RajaGrafindo Persada. 
Trógolo, M., \& Medrano, A. L. (2012). Personality traits, difficulties in emotion regulation and academic satisfaction in a sample of argentine college student. International Journal of Psychological Research, 5(2), 30-39.

Wike, H. K. (2015). Examining the relationship between physical activity, psychological well-being, and stress in a college population (Tesis tidak dipublikasikan). University of Tennessee, Amerika Serikat. 